\title{
ESSENTIAL OIL OF LITHRAEA MOLLEOIDES (VELL.): CHEMICAL COMPOSITION AND ANTIMICROBIAL ACTIVITY
}

\author{
Mario Tsunezi Shimizu ${ }^{1 *}$; Leandro de Jesus Franco Bueno²; Rosa Fátima Oliveira Rodrigues²; \\ Fabiano Augusto Sallowicz ${ }^{2}$; Alexandra Christine Helena Frankland Sawaya ${ }^{2}$; Márcia Ortiz Maio Marques ${ }^{3}$
}

${ }^{1}$ Universidade Estadual Paulista, São José dos Campos, SP, Brasil; ${ }^{2}$ Universidade de São Francisco, Bragança Paulista, SP, Brasil; ${ }^{3}$ Seção de Fitoquímica, Instituto Agronômico de Campinas, Campinas, SP, Brasil

Submitted: March 21, 2005; Approved: July 18, 2006

\begin{abstract}
Lithraea molleoides (Vell.) (Anacardiaceae) is a tree found in Brazil, Paraguay, Bolivia, Uruguay, Argentina and Chile. It is popularly used in the form of alcoholic extracts, decoctions and infusions for the treatment of cough, bronchitis, arthritis, diseases of the digestive system and as diuretic, tranquilizer, haemostatic and tonic agent. The objectives of this study were the extraction of the essential oil of the mature fruit, leaves and aerial parts of the plant and quantification of the yield thereof; the identification and quantification of the principal components of the essential oil and the determination of its antimicrobial activity against bacteria and yeast. The essential oil yield of the mature fruits was $1.0 \%$ but essential oil was not detected in leaves and flowery branches. The gas chromatograph-mass spectrometer (GC-MS) analysis of the essential oil of the mature fruits detected the presence of limonene (89.89\%), $\alpha$-pinene (3.48\%), $\beta$-pinene (2.63\%), $\alpha$-terpineol $(1.27 \%)$, myrcene $(0.64 \%)$, sabinene hydrate $(0.54 \%)$, 4-terpineol $(0.28 \%)$, camphene $(0.22 \%)$ and $\Delta$-3-carene $(0.13 \%)$. The essential oil was active against just a few of the Gram-positive bacteria and yeast tested and did not present antimicrobial activity against Gram-negative bacteria.
\end{abstract}

Key words: Lithraea molleoides, essential oil, chemical composition, antimicrobial activity

\section{INTRODUCTION}

Lithraea molleoides (Vell.) Engler, Anacardiaceae, is a tree between 2.5 and 8 meters height found in Brazil, Paraguay, Bolivia, Uruguay, Argentina and Chile $(8,11)$. It is popularly used in the form of alcoholic extracts, decoctions and infusions for the treatment of cough, bronchitis, arthritis, diseases of the digestive system and as diuretic, tranquilizer, haemostatic and tonic agent. It also possess antimicrobial, antiviral, cytotoxic and immunomodulatory activities $(8,11,13,15)$. Nevertheless it can cause allergic sensitivity, skin disease, fever and visual problems in sensitive individuals.

In Brazil, Lithraea molleoides (Vell.) Engler is popularly known, as "aroeira", "aroeira brava", "aeroeirinha" and "aroeira branca". In Uruguay and Argentina, it is commonly called "arueira, chicha, molle de beber" and evil tree $(1,3,11)$. It has also been referred to under the following scientific names:
Schinus molleoides (Vell.) Engler, Schinus brasiliensis Marchand ex Cabrera $(3,14)$; Lithraea aroeirinha March., Schinus leucocarpus M. (3); Lithraea molleoides var. lorentziana Lillo, Lithraea ternifolia (18).

Studies of the morphological characterization of this plant have been carried out by Barkley (3) and Carmello et al. (4). Phytochemical characterization has demonstrated the presence of tannins, flavonoids and lignans in mature fruit (4). Hydroalcoholic extracts of the leaves contain 3-pentadecylcatechol, 3-heptadecenylcatechol, 3-hepta-dec-dienylcatechol and 3pentadecenylcatechol (1). Methanolic extracts of the leaves contain (Z, Z, Z)-5-(trideca-4,7,10-trienyl)-resorcinol, (Z, Z, E)5-(trideca-4, 7,10-trienyl) resorcinol and (Z)-5-(trideca-4-enyl) resorcinol (18).

Although the essential oils of various popularly used medicinal plants, such as Taxodium distichum L. (7), Schinus molle Linn (9), Schinus terebinthifolius (16), Origanum vulgare,

*Corresponding Author. Mailing address: Av. Jorn. Napoleão Monteiro, 179, Jardim Colinas. 12242-180. São José dos Campos, SP, Brasil. Tel.: (+5512) 3911-8838. E-mail: mtshimizu@terra.com.br 
Aloysia triphylla (12) and Cordia verbenacea DC (5), have been obtained and studied, this study had not yet been carried out on Lithraea molleoides (Vell.) Engler. The aims of the present study were: (i) the extraction of the essential oil of the mature fruits, leaves and aerial parts of the plant and quantification of the yield thereof; (ii) the identification and quantification of the principal components of the essential oil and (iii) the determination of its antimicrobial activity against bacteria and yeast.

\section{MATERIALS AND METHODS}

\section{Plant samples}

The fruits and aerial parts of Lithraea molleoides (Vell.) were collected from wild specimens in Bragança Paulista, São Paulo, Brazil, during the morning. After morphological and microscopical characterization of the plant, a voucher sample was deposited in the Botanical Laboratory of the Universidade São Francisco under the number 0076. The aerial parts of the plant were made up of the flowers, mature fruits, leaves and part of the stem.

\section{Essential oil extraction}

The essential oil of the fresh aerial parts, leaves and fruit was extracted using a modified Clevenger apparatus by the hydro-distillation technique. After extraction, the volume of essential oil obtained was measured and the essential oil maintained in hermetically sealed glass containers with rubber lids, covered with aluminum foil to protect the contents from light and kept under refrigeration at $8^{\circ} \mathrm{C}$ until used.

\section{Identification and quantification of the components of the essential oil}

The essential oil obtained was diluted in the proportion of $5 \mu \mathrm{L}$ of essential oil to $1.5 \mathrm{~mL}$ of ethyl acetate (Merck, Darmstadt, Germany). One microliter of this solution was injected in a Shimadzu QP 5000 gas chromatograph-mass spectrometer, with a DB-5 capillary column ( $30 \mathrm{~m}$ x 0.25 i.d. x $0.25 \mu \mathrm{m}$ coating thickness). Helium as the carrier gas, flow $1.7 \mathrm{~mL} / \mathrm{min}$. The program used was: injector with a $1 / 30$ split at a temperature of $240^{\circ} \mathrm{C}$; detector at $230^{\circ} \mathrm{C}$; temperature program $50^{\circ} \mathrm{C}(5 \mathrm{~min}) ; 60$ $240^{\circ} \mathrm{C}$ at $3^{\circ} \mathrm{C} / \mathrm{min}$. The quadrupole mass analyzer contained an EI ion source with filament potential of $70 \mathrm{eV}$.

In order to determine the Kovats index of the components, a mixture of alkenes $\left(\mathrm{C}_{9}-\mathrm{C}_{24}\right)$ was added to the essential oil before injecting in the GC-MS equipment and analyzed under the same conditions as above. The compounds were identified by computer searches in commercial libraries (NIST) and by their Kovats retention index.

\section{Microbial strains}

In order to evaluate the antimicrobial activity of the essential oil of Lithraea molleoides (Vell.), the following Gram-positive bacteria were used: five strains of Staphylococcus aureus isolated from patients and two ATCC strains of S. aureus (ATCC 6534, ATCC 6538); two strains of Staphylococcus epidermidis isolated from patients and one ATCC strain of S. epidermidis (ATCC 27262). The following Gram-negative bacteria were used: three strains of Escherichia coli isolated from patients, three strains of Klebsiella pneumoniae isolated from patients and one ATCC strain of K. pneumoniae (ATCC 10031); three strains of Proteus mirabilis isolated from patients, one strain of Enterobacter cloacae (ATCC 13047), one strain of Salmonella thiphymurium (ATCC 13311) and one Pseudomonas aeruginosa strain. The following yeast were used: four strains of Candida albicans, three strains of Candida tropicalis including one ATCC strain (13803), three strains of Candida dubliniensis and one Candida lusitaneae strain. The bacteria were grown on BHI agar (Difco Laboratories, Detroit, MI, EUA) and the yeast were grown on Sabouraud dextrose agar (Difco). The suspension of the microorganisms used in the tests was obtained from $24 \mathrm{~h}$ cultures and suspended in sterile saline solution to obtain concentrations of approximately $10^{8} \mathrm{CFU} / \mathrm{mL}$ by comparison to tube no. 1 of the MacFarland scale.

\section{Agar diffusion in plates with steel cylinders}

The $50 \mathrm{~mm}$ diameter plates for this test were prepared using approximately $20 \mathrm{~mL}$ of sterile Mueller-Hinton agar (Difco) for the bacteria and Sabouraud dextrose agar (Difco) for the yeast. The surface of the plates was inoculated using a sterile swab containing the microbial suspension and allowed to dry. Sterile steel cylinders were put on the surface and filled with $80 \mu \mathrm{L}$ of the essential oil and incubated at $37^{\circ} \mathrm{C}$ for $24-48 \mathrm{~h}$. The diameter of the growth inhibition zones surrounding the cylinder was measured. All tests were performed in duplicate.

\section{RESULTS}

The macro- and microscopic morphological characterization of the plant confirmed the identity of the specimens used to be Lithraea molleoides (Vell.). The yield of essential oil of the fruit was $1.0 \%(\mathrm{v} / \mathrm{w})$. In the flowering aerial parts and leaves the essential oil was not found. The results of gas chromatographymass spectrometric analysis (Fig. 1) showed 12 peaks and the 9 most intense peaks corresponded to $99.08 \%(\mathrm{w} / \mathrm{w})$ of the essential oil (Table 1).

The results of the antimicrobial activity of the essential oil are reported in Table 2. No inhibition zones were observed for the Gram-negative bacteria.

\section{DISCUSSION}

Essential oil was found in the fruit, but not in leaves and aerial parts of Lithraea molleoides (Vell.). As this is the first study of the essential oil in this plant, no information could be 


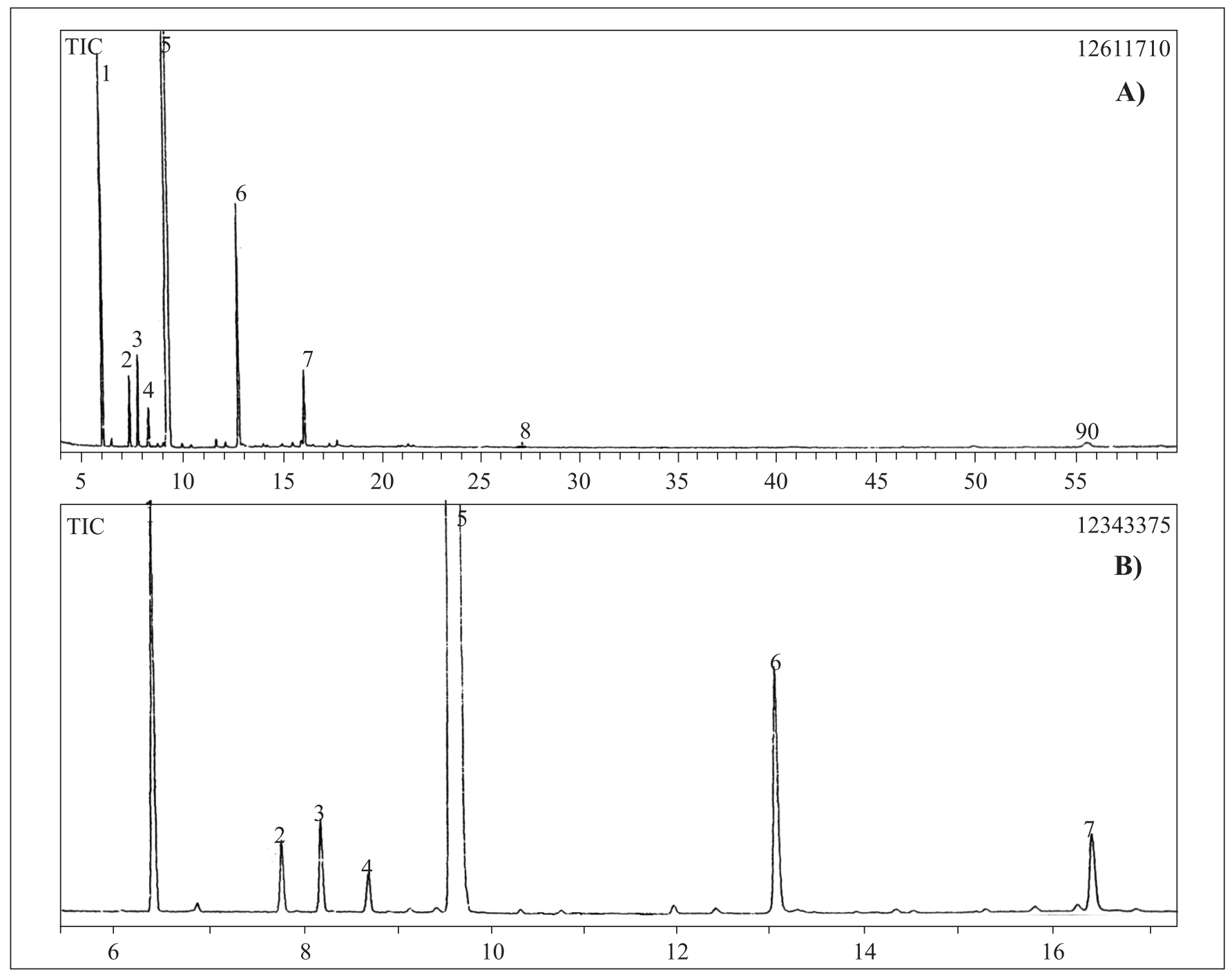

Figure 1. (A) The chromatogram obtained of the essential oil of the fruit of Lithraea molleoides (Vell.) Engler and (B) the same chromatogram expanded 5-18 min, obtained using a Shimadzu QP 5000 gas chromatograph-mass spectrometer, with a DB-5 capillary column. Peaks identified in Table 1.

found in literature as the yield of essential oil in various parts of this plant. The essential oil was composed mainly of limonene (89.89\%), $\alpha$-pinene $(3.48 \%), \beta$-pinene (2.63\%) and $\alpha$-terpineol (1.27\%); making up $97.27 \%$ of the essential oil. The other identified components made up $1.81 \%$ of the essential oil. Unidentified minor components made up only $0.92 \%$.

According to the results of the antimicrobial test, the essential oil of Lithraea molleoides (Vell.) had a low activity against the microorganisms tested. Just $30 \%$ of the Grampositive bacteria tested and $42.86 \%$ of the yeasts tested were sensitive. All the Gram-negative bacteria tested were resistant to the essential oil. Other studies of essential oil components reported by Tampieri et al., (17) showed that the monocyclic terpenes, limonene and $\alpha$-pinene, were not active against $C$. albicans and cyclic monoterpenic alcohol, 4-terpineol, had low activity. On the other hand aromatic bicyclical $\beta$-pinene showed strong inhibitory activity at low concentrations. As the essential oil of Lithraea molleoides (Vell.) is mainly composed of limonene these results explain the low antimicrobial activity.

As the essential oil of Lithraea molleoides (Vell.) has a low antimicrobial activity, its popular use for the treatment of cough, bronchitis, diseases of the digestive system and others, must stem from another pharmacological mechanism. Other clinical applications of this plant are presently under study, such as its anti-inflammatory and healing properties; as well as its toxic effects on tissues. Moreover, limonene, the major 
Table 1. Composition of the essential oil of Lithraea molleoides (Vell.) fruit analyzed by gas chromatograph-mass spectrometer

\begin{tabular}{ccccc}
\hline $\begin{array}{c}\text { Peak } \\
\text { number* }\end{array}$ & Compound & $\begin{array}{c}\text { Kovats index } \\
\text { found }\end{array}$ & $\begin{array}{c}\text { Kovats index } \\
\text { literature }\end{array}$ & $\begin{array}{c}\mathrm{TIC}^{\mathrm{a}} \\
(\%)\end{array}$ \\
\hline 1 & $\alpha$-pinene & 933 & 939 & 3.48 \\
2 & camphene & 949 & 953 & 0.22 \\
3 & $\beta$-pinene & 976 & 980 & 2.63 \\
4 & myrcene & 990 & 991 & 0.64 \\
5 & $\Delta$-3-carene & 1009 & 1011 & 0.13 \\
6 & limonene & 1029 & 1031 & 89.89 \\
7 & sabinene hydrate & 1094 & 1097 & 0.54 \\
8 & ni & 1114 & - & 0.66 \\
9 & 4-terpineol & 1176 & 1117 & 0.28 \\
10 & ni & 1188 & - & 0.13 \\
11 & $\alpha$-terpineol & 1189 & 1189 & 1.27 \\
12 & ni & 1229 & - & 0.13 \\
& & $\%$ identified & & 99.08 \\
\hline
\end{tabular}

* numbers correspond to the peaks observed in the chromatogram (Figure 1); a TIC (\%) total ion current, depends on the characteristics of the compound concerned and is not a true quantification. ni unidentified minor components.

Table 2. Diameter of the growth inhibition zones of Gram-positive bacteria and Candida species by the essential oil $(80 \mu \mathrm{L})$ of Lithraea molleoides (Vell.) measured by the agar diffusion method with steel cylinders

\begin{tabular}{|c|c|}
\hline Gram-positive bacteria & $\begin{array}{l}\text { ameter of inhibition } \\
\text { zone }(\mathrm{mm})\end{array}$ \\
\hline Staphylococcus aureus ATCC 6534 & 15 \\
\hline Staphylococcus aureus ATCC 6538 & 14 \\
\hline Staphylococcus aureus 131 & 0 \\
\hline Staphylococcus aureus 5164 & 0 \\
\hline Staphylococcus aureus 5051 & 0 \\
\hline Staphylococcus aureus 5053 & 0 \\
\hline Staphylococcus aureus 5039 & 0 \\
\hline Staphylococcus epidermidis ATCC 27262 & 262 \\
\hline Staphylococcus epidermidis 7485 & 0 \\
\hline Staphylococcus epidermidis 7486 & 0 \\
\hline Candida albicans ICB 58 & 0 \\
\hline Candida albicans 4161 & 0 \\
\hline Candida albicans FCF14.1 & 0 \\
\hline Candida tropicalis ATCC 13803 & 0 \\
\hline Candida tropicalis 221 & 0 \\
\hline Candida tropicalis 75 & 15 \\
\hline Candida dubliniensis 539 & 25 \\
\hline Candida dubliniensis 34 & 11 \\
\hline Candida lusitaneae & 0 \\
\hline
\end{tabular}

component $(89.89 \%)$ found in the essential oil of Lithraea molleoides (Vell.), although bereft of antimicrobial activity (17) has anti-carcinogenic activity (2) and can be used in medical dissolution of gallstones $(6,10)$. The results of the analysis of the chemical composition of the essential oil of Lithraea molleoides (Vell.) indicates several paths to be pursued in order to elucidate the pharmacological mechanisms of its many popular medicinal uses.

\section{RESUMO}

\section{Óleo essencial de Lithraea molleoides (Vell.): composição química e atividade antimicrobiana}

Lithraea molleoides (Vell.) (Anacardiaceae) é uma árvore encontrada no Brasil, Paraguai, Bolívia, Uruguai, Argentina e Chile. É popularmente usada na forma de extrato alcoólico, decocção e infusão para o tratamento de tosse, bronquite, artrite, doenças do sistema digestivo, como diurético, tranqüilizante, hemostático e tônico. O objetivo do presente estudo foi a extração do óleo essencial dos frutos maduros, folhas e outras partes aéreas da planta e o rendimento do mesmo; a identificação e quantificação dos principais componentes e a determinação da atividade antimicrobiana. $\mathrm{O}$ rendimento do óleo essencial dos frutos maduros foi de $1 \%$, entretanto, não foi encontrado óleo essencial nas partes aéreas da planta. A análise do óleo essencial por cromatografia gasosa com espectrometria de massa, mostrou a presença de limoneno $(89,89 \%)$, \pm -pineno $(3,48 \%),{ }^{2}$-pineno $(2,63 \%)$, \pm -terpineol $(1.27 \%)$, mirceno $(0,64 \%)$, sabineno $(0,54 \%)$, 4-terpineol $(0,28 \%)$, canfeno $(0,22 \%)$ e "-3careno $(0,13 \%)$. O óleo essencial foi ativo contra algumas bactérias Gram positivas e leveduras testadas e não apresentou atividade contra bactérias Gram negativas.

Palavras-chave: Lithraea molleoides, óleo essencial, composição química, atividade antimicrobiana

\section{REFERENCES}

1. Alé, S.I.; Ferreira, F.; González; Epstein, W. Allergic contact dermatitis caused by Lithraea molleoides and Lithraea brasiliensis: identification and characterization of the responsible allergens. Am. J. Contact. Dermat., 8, 144-149, 1997.

2. Anderson, P.; Kwon, R.; Elson, C.E. A comparison of the anticarcinogenic activities of two monoterpenes, D-limonene and geraniol. Cancer Res., 1, 22, 1993.

3. Barkley, F.A. Anacardiaceae: Rhoideae: Lithraea. Phytologia, 8, 329-365, 1962

4. Carmello, S.M.; Machado, S.R.; Gregório, E.A. Ultrastrutural aspects of the secretory duct development in Lithraea molleoides (Vell.) Engl. (Anacardiaceae). Rev. Bras. Bot., 18, 95-103, 1995.

5. Carvalho, P.M.; Rodrigues, R.F.O.; Sawaya, A.C.H.F; Marques, M.O.M.; Shimizu M.T. Chemical composition and antimicrobial activity of the essential oil of Cordia verbenacea D.C. J. Ethnopharmacol., 95, 297-301, 2004. 
6. Crowell, P.L. Prevention and therapy of cancer by dietary monoterpenes. J. Nutr., 129, 775, 1999.

7. El Tantawy, M.E.; El Sakhawy, F.S.; El Sohly, M.A.; Ross, S.A. Chemical composition and biological activity of the essential oil of the fruit of Taxodium distichum L. rich growing in Egypt. J. Essent. Oil Res., 11, 386-392, 1999.

8. Fernández, T.; Cerdá, T.; Risco, P.; López, E.; Clavin, M.; Hnatyzyn, O.; Cañigueral, S.; Hajos, S.; Ferraro, G.; Alvarez, E. Immunomodulating properties of Argentine plants with ethnomedicinal use. Phytomedicine, 9, 546-552, 2002.

9. Gundidza, M. Antimicrobial activity of essential oil from Shinus molle Linn. Cent. Afr. J. Med., 39, 231-234, 1993.

10. Hirotsune, I.; RyoichI, T.; KenichI, T.; Fumio, Y.; Atsuo, K.; Takeharu, H.; Hidehiko, S. Medical dissolution of gallstones: clinical experience with d-limonene as a simple, safe and effective solvent. Dig. Dis. Sci., 36(2), 200-209, 1991.

11. Kott, V.; Barbini, L.; Cruañes, M.; Muños, J.D.; Vivot, E.; Cruañes, J.; Martino, V.; Ferraro, G.; Cavallaro, L.; Campos, R. Antiviral activity in Argentine medicinal plants. J. Ethnopharmacol., 64, 79-84, 1999.

12. López, A.G.; Theumer, M.G.; Zygadlo, J.A.; Rubinstein, H.R. Aromatic plants essential oils activity on Fusarium verticillioides Fumonisin B1, production in corn grain. Mycopathologia, 158, 343349, 2004.
13. Penna, C.; Marino, S.; Vivot, E.; Cruañes, M.C.; Muñoz, J.D.; Cruañes, J.; Ferraro, G.; Gutkind, G.; Martino, V. Antimicrobial activity of Argentine Plants used in the treatment of infectious diseases. Isolation of active compounds from Sebastiania brasiliensis. J. Ethnopharmacol., 77, 37-40, 2001.

14. Pienaar, M.E.; Teichman, I.V. The generic position of Lithraea brasiliensis Marchand (Anacardiaceae), evidence from fruit and seed structure. Bot. J. Linn., 126, 327-337, 1998.

15. Ruffa, M.J.; Ferraro, G.; Wagner, M.L.; Calcagno, M.L.; Campos, R.H.; Cavallaro, L. Cytotoxic effect of Argentine medicinal plant extracts on human hepatocellular carcinoma cell line. $J$. Ethnopharmacol., 79, 335-339, 2002.

16. Singh, A.K.; Singh, J.; Gupta, K.C.; Brophy, J.J. Essential oil of leaves and inflorescence of Schinus terebinthifolius: an exotic plant of India. J. Essent. Oil Res., 10, 697-699, 1998.

17. Tampieri, M.P.; Galuppi, R.; Macchioni, F.; Carelle, M.S.; Falcioni, L.; Cioni, P.L.; Morelli, I. The inhibition of Candida albicans by selected essential oils and their major components. Mycopathologia, 159, 339-345, 2005

18. Valcic, S.; Wächter, G.A.; Eppler, C.M.; Timmermann, B.N. Nematicidalalkylene resorcinol from Lithraea molleoides. J. Nat. Prod., 65, 1270-1273, 2002. 